\title{
The Development of East Asian Libraries in North America
}

\author{
Eugene W. Wu
}

\begin{abstract}
The development of East Asian libraries in North America is of recent history. Prior to World War II there were only some half dozen East Asian collections in the United States and Canada. But that number began to increase rapidly after the War. With the establishment of new East Asian collections at universities, problems concerning collection development, cataloging, and personnel began to be a common concern. A series of efforts led by the American Library Association (ALA), the Library of Congress (LC), and the Association for Asian Studies (AAS) led to the developing of national cataloging standards for East Asian materials, and the eventual founding of the Committee on East Asian Libraries (later renamed Council on East Asian Libraries, CEAL) of the Association for Asian Studies to better coordinate cataloging, collection development, and personnel training, and later on the introduction of automation in East Asian libraries. This essay is an attempt to trace that development by stage, with tributes paid to two pioneers in that development: Dr. A. Kaiming Chiu, the founding Librarian of the Harvard-Yenching Library of Harvard University, and Dr. Mary C. Wright, the founding Curator of the Chinese Collection at the Hoover Institution, Stanford University. Some comments are also made on the application of technology in East Asian libraries.
\end{abstract}

Keywords $\mathrm{CEAL} \cdot \mathrm{ALA} \cdot \mathrm{AAS} \cdot \mathrm{LC} \cdot \mathrm{RLG} \cdot \mathrm{OCLC} \cdot \mathrm{CCRM} \cdot$ East Asian libraries • A. Kaiming Chiu $\cdot$ Mary C. Wright

This address was delivered before the Plenary Session of the Council on East Asian Libraries, Association for Asian Studies, at its Annual Meeting on March 8, 2000 in San Diego, California, and published under the title "CEAL At the Dawn of the 21st Century" in the Journal of East Asian Libraries, no. 20 (June 2000). It has been revised and updated, with endnotes, for republication here.

Eugene W. Wu was founding Curator of the East Asian Collection at the Hoover Institution at Stanford University in 1961, and later Librarian of the Harvard-Yenching Library at Harvard University from 1965-1997. Email: Ewwu@aol.com

\author{
E. W. Wu $(\bowtie)$ \\ Harvard-Yenching Library, Harvard University, Cambridge, USA \\ e-mail: Ewwu@aol.com \\ C. Chen, R. Larsen (eds.), Library and Information Sciences, \\ DOI 10.1007/978-3-642-54812-3_11, (C) The Author(s) 2014
}




\section{The Beginning}

The development of East Asian libraries in North America is of recent history. Prior to World War II there were only some half dozen East Asian collections in the United States and Canada. But that number began to increase rapidly after the war, and problems concerning management and operation became a matter of common concern. In 1948 a group of concerned scholars and librarians gathered at the annual meeting of the American Library Association (ALA) in Atlantic City to discuss these problems. ${ }^{1}$ Although it was an informal meeting, the discussion that began at that time eventually led to a concerted organizational movement that made possible the phenomenal growth of East Asian libraries in North America, particularly in the United States, in the last six decades. ${ }^{2}$

This library development followed closely the spread of East Asian Studies in North America in the postwar years. Before that time a few universities had offered some courses on East Asia (then referred to as the Far East), but full-fledged study of East Asia, in all the disciplines of the humanities and social sciences, did not develop until after the end of the Second World War. The war in the Pacific, the transformation of Japan into a democracy, the communist revolution in China, and the Korean War contributed to a heightening of American awareness of the importance of East Asia in a changing world, and of the need for better understanding of their histories and civilizations. The universities, with generous foundation and government support, responded by expanding their teaching and research programs on East Asia, and today, after sixty years, East Asian studies in the United States is probably the largest and most comprehensive in the Western world. A concomitant development in this academic enterprise was the building of library resources. Although several American libraries had begun collecting in the East Asian languages long before World War II (the Library of Congress began as early as 1869, Yale started in 1878, Harvard in 1879, UC-Berkeley in 1896, Cornell in 1918, Columbia in 1920, Princeton in 1926, and Chicago in 1936), they all experienced their greatest growth after 1945. A number of today's major collections, such as those at Michigan, Stanford (incorporating the former collections of Hoover Institution), University of Washington, and UCLA, came into being only in the late 1940s; and others such as Illinois, Indiana, and Wisconsin, in the 1960s.

With the establishment of new East Asian collections at universities, problems concerning acquisitions, cataloging, and personnel began to be a common concern. That was the reason for the 1948 Atlantic City meeting. Those present were looking

${ }^{1}$ Elizabeth Huff, "The National Committee on Oriental Collections, 1948-1952,": Library Resources on East Asia: Reports and Working Papers for the Tenth Annual Meeting of the Committee on American Library Resources on the Far East, Association for Asian Studies, Inc., at the Palmer House, Chicago, March 21, 1967 (Zug, Switzerland: Inter Documentation Company AG, 1968) pp. 16-17. Also, Edwin G. Beal, "The Committee on East Asian Libraries: A Brief History," Committee on East Asian Libraries Newsletter, no 41 (Sept. 1973), Appendix I, pp. $42-43$.

${ }^{2}$ According to 1957 statistics, the earliest available data on East Asian libraries, 20 libraries reported a total holding of 2,490.000 volumes. Those numbers increased to 50 libraries with a total holding of 17,900.000 volumes, not including serial titles or materials in electronic format. For detailed annual statistics from 1957 seehttp://lib.ku.edu/ceal/stat/ 
for cooperative solutions to these problems. A decision was made at that meeting to create an informal committee, to be named the National Committee on Oriental Collections in the U.S. and Abroad, to explore possible ways to achieve that purpose. It is instructive to note that the problems they discussed - acquisitions, cataloging, and the training of personnel - are still among our concerns today, albeit in a different context from that of sixty years ago. In all likelihood we will continue discussing them for years to come. This reminds us once again that the basic mission of the library - building collections and providing service - never changes, only the way that mission is carried out. The informal committee created in Atlanta was replaced a year later, in 1949, by an official Joint Committee on Oriental Collections, sponsored by the Far Eastern Association (the predecessor of the Association for Asian Studies) and the American Library Association (ALA). ${ }^{3}$ This was the first time in the history of American libraries that an official body was established by the library and the scholarly communities to address the problems associated with East Asian library collections in the United States. The significance attached to this new development can be seen in the composition of the Joint Committee, which comprised three members appointed by the Far Eastern Association and three by the American Library Association. Representing the former were Arthur H. Hummel, Chief of Orientalia Division, Library of Congress; Osamu Shimizu, Head of Japanese Section, Orientalia Division, Library of Congress; and Elizabeth Huff, Head of East Asiatic Library, UC-Berkeley. The latter was represented by Warner G. Rice, Director of the University of Michigan Library; Charles H. Brown, Director of Library, Iowa State College; and Robert B. Downs, Director of the University of Illinois Library and UI's Library School. Howard Linton, Curator of the East Asian Library at Columbia University, who belonged to both associations, became the executive secretary. It was an auspicious beginning. Among the salient accomplishments of the Joint Committee in its three-years of existence was the agreement by the Library of Congress to reproduce for purchase unedited Chinese and Japanese catalog cards sent in by cooperating libraries under a new program named Oriental Card Reproduction Project. It was not cooperative cataloging, to be sure, but a mechanism for catalog card exchange, as it were, which did not exist before. ${ }^{4}$ The Joint Committee ceased to function in 1952, but the recognition that no meaningful cooperative development of East Asian libraries in the United States would be possible without a satisfactory solution of one of its basic functions of a library, namely cataloging, prompted ALA to appoint in 1954 a Special Committee on Cataloging Oriental Materials under its Cataloging and Classification Division. In 1957 the name was changed to Special Committee on Cataloging Far Eastern Materials of the American Library Association because the Special Committee was spending most of its time working on problems involving materials in the Far Eastern languages. Because of the importance of its work this Special Committee was made in 1958 a standing committee of ALA under the name Far Eastern Materials Committee..$^{5}$ In the same

${ }^{3}$ Huff, op. cit p. 42.

${ }^{4}$ ibid.

${ }^{5}$ G. Raymond Nunn, "Development of Cooperative Cataloging and Resources for East Asian Collections, 1954-1963," Library Resources on East Asia: Reports and Working Papers for the Tenth Annual Meeting of the Committee on American Library Resources on the Far East...p. 18. 
year, the Association for Asian Studies (AAS), at the urging of East Asian libraries, also established a Committee on American Library Resources on the Far East (CALRFE) ${ }^{6}$

\section{Developing National Cataloging Standards for East Asian Materials}

The Far Eastern Materials Committee was chaired by G. Raymond Nunn, then Head of the Asia Library, University of Michigan. (He was succeeded as chair by Charles E. Hamilton of the East Asiatic Library of the University of California in Berkeley.) Its members were mostly heads of large East Asian libraries with cataloging experience. This committee occupies a very special place in the history of the development of East Asian libraries in North America, as it was under its and LC's leadership a set of national standards for cataloging East Asian materials was established for the first time. It was the result of four years of intensive collaborative work, from 1954 to 1958, by this committee and LC's Oriental Processing Committee (OPC). These two bodies, in the most meticulous fashion, worked through the twin American standards for cataloging - ALA Cataloging Rules for Author and Title Entries and Rules for Descriptive Cataloging in the Library of Congress-and amended every rule that had implications for cataloging East Asian materials. The result was a major series of amendments to the two sets of rules, which were then approved by both ALA and LC and adopted as national standards. They remain so today, with modifications as incorporated in the Anglo-American Cataloging Rules II (AACRII). ${ }^{7}$ This was a significant milestone in the history of East Asian libraries in North America, for in those days not only were there no computers, there were even no national standards for cataloging Chinese, Japanese, or Korean materials. Every library was on its own, using its own format and following its own rules, although many opted for the Harvard-Yenching Classification Scheme. No library used subject headings (a few maintained a classified catalog) and there was little or no authority work. There was even disagreement as to whether the main entry should be by author or title. So, what the two committees accomplished under those circumstances was indeed epoch-making. There is a Chinese saying: "People before us planted trees, we can now enjoy the shade." We will always be indebted to these two committees for their lasting contributions to our profession. In this connection we should remember in particular the leadership provided to the work of the two committees by G. Raymond Nunn, Lucile Morsch, C. Sumner Spalding, and Charles H. Hamilton. Ray Nunn was an indefatigable workhorse, and he guided the work of the Special Committee with that spirit. Lucile Morsch and C. Sumner

$\overline{{ }^{6} \text { ibid. p. 19. Also, Beal, op. cit. }}$

${ }^{7}$ Edwin G. Beal, Jr. "Discussion of Tsuen-Hsuin Tsien's paper. "East Asian Collections in America," in Tsuen-Hsuin Tsien and Howard Winger, ed., Area Studies and the Library, The Thirtieth Annual Conference of the Graduate Library School, May 20-22, 1965 (Chicago \& London: The University of Chicago Press, 1965), pp. 75-76. 
Spalding, who were successive chairs of the OPC in their capacity as chief of LC's Descriptive Cataloging Division, were incisive and always willing to meet us halfway. Charles Hamilton, chief cataloger at the East Asiatic Library of UC-Berkeley, who had the rare ability to discern linkages among seemingly disparate rules and their potential impact on cataloging East Asian materials, and his arguments often revealed our ignorance of the subtlety in the intent of some of the rules. It can be safely said that without his participation, the work of amending the rules would have been much more difficult.

The adoption of the amended rules as national standards did not mean, however, the end of East Asian libraries' cataloging problems. The new challenge was implementation, and there was great hope that everyone's dream of shared cataloging might come true at last. Toward that end LC established in 1958 a Far Eastern Section in the Processing Department under the direction of Warren Tsuneishi, who would later become Chief of the Orientalia Division and the first director of the Area Studies Department at LC. The purpose of the new section was to introduce a cooperative cataloging program for East Asian publications, patterned after what LC had been doing for decades for publications in other languages. Unfortunately, this program did not work as expected, and it was soon terminated mainly because of insufficient manpower at LC to do the editing that was required to bring cataloging copies from the participating libraries up to the very strict LC standard. The demise of this short-lived program notwithstanding, the drive toward some sort of shared cataloging did not lose its momentum altogether. It survived in part and in a different form when LC established a Japan office under its National Program of Acquisitions and Cataloging (NPAC). The purpose of NPAC was to insure both adequate coverage of current publications LC was acquiring from around the world and the speedy availability of bibliographical records for them for general use. The NPAC Japan office, under the direction of Andrew Kuroda, Head of the Japanese Section of LC's Orientalia Division, did just that for Japanese publications for a number of years. It was a very useful program. Unfortunately, it had to be dismantled for budgetary reasons. At the time the NPAC Japan office was established, discussion began on establishing a similar program for Chinese-language materials, perhaps in Hong Kong, both within and without the Library of Congress. (This was in the early 1970s, and there were no diplomatic relations between Washington and Beijing. It was impossible even to think of setting up a NPAC center on the China mainland at that time.) However, the discussion never went very far. Since libraries in those days all looked to LC to get things done, East Asian libraries thought it best to wait for LC to come up with a solution to deal with the Chinese acquisitions and cataloging problems for everyone, and they made a point of engaging LC in the discussion they were having among themselves. The Harvard-Yenching Library took the lead and invited twelve large East Asian libraries and the Library of Congress to a series of meetings on Chinese cooperative cataloging, the first in New York in 1972, followed by a second in Chicago in 1973, and a third in Boston in 1974. An Ad Hoc Committee on Chinese Cooperative Cataloging was set up at the first meeting to investigate the feasibility of establishing such a program. The subsequent deliberations centered on several related issues: the slowness in LC's distribution of 
its printed Chinese catalog cards; the exclusion from the National Union Catalog published by LC of records in any East Asian language, resulting in the costly duplication of cataloging efforts among East Asian libraries. In response, LC proposed the compilation of a new publication to be called Chinese Cooperative Catalog which would include all cards submitted by participating libraries. There were some misgivings about the LC proposal, the main concern being the likelihood that once the Chinese Cooperative Catalog was published, cataloging cards for East Asian publications may be permanently excluded from the National Union Catalog. This whole matter was turned over to the Committee on East Asian Libraries (CEAL), which at that time had appointed a Subcommittee on the National Union Catalog, and the Ad Hoc Committee was dissolved. The CEAL Subcommittee continued the discussion on the LC proposal, but there was insufficient support for it among the East Asian libraries, and the matter was dropped. East Asian libraries had to wait for a decade until the mid-1980s before a truly national and international shared cataloging program was in place, thanks to technology that brought us online cataloging and the services of the Research Libraries Group (RLG) and the Online Computer Library Center (OCLC).

\section{The Birth of the Committee on East Asian Libraries}

It is appropriate to mention at this point the creation of the Committee on East Asian Libraries (CEAL) and the vital role it played in the development of East Asian libraries in North America. Before 1967 there was no national organization of East Asian libraries. All developmental activities were carried out under the name of committees. The above-mentioned CALRFE came close to being a quasi-national organization, but in spite of its many accomplishments, CALRFE operated without a charter setting forth its functions, membership requirements, or voting procedures. It was run almost single-handedly by a chairperson, appointed by the Board of Directors of the Association for Asian Studies (AAS), who was also responsible for putting out a newsletter. The arrangement was not satisfactory, especially when the number of East Asian libraries was increasing rapidly. So, in 1963 CALRFE was reorganized with an Executive Group of seven members, also appointed by the Association for Asian Studies (AAS), in addition to the chairperson. ${ }^{8}$ At the CALRFE annual meeting in 1967 East Asian libraries approved a set of Procedures proposed by the new Executive Group setting forth CALRFE's objectives, functions, and operating procedures, and it was at this time the name Committee on American Library Resources on the Far East (CALRFE) was changed to Committee on East

\footnotetext{
${ }^{8}$ Tsuen-Hsuin Tsien T-H "Report of CALRFE Programs and Activities for 1966-1967," Library Resources on East Asia: Reports and Working Papers for the Tenth Annual Meeting of the Committee on American Library Resources on the Far East...p. 28.
} 
Asian Libraries (CEAL) of the Association for Asian Studies (AAS) ${ }^{9}$ The Procedures became the basic operating document for CEAL. It was amended several times later, most significantly in 1980 by the requirement that all officers of CEAL, including the chair, members of the Executive Group as well as the chairs of the subcommittees be elected rather than appointed by AAS. It was a change welcomed by all East Asian libraries, and it has served the Easy Asian library community well over the years. In 1995 the name Committee on Ease Asian Libraries was changed to Council on East Asian Libraries (still known as CEAL) and it remained under the Association for Asian Studies. ${ }^{10}$

\section{Issues in Collection Development}

As already mentioned, many universities introduced teaching and research programs on East Asia in the post-World War II years, and new East Asian collections came to be established at those institutions. The collection development needs of these newly established libraries were somewhat different from those at the older libraries. The newer ones had to start from the ground up while the older ones, having already established core collections of the basic materials, had the advantage of being able to concentrate on current publications. Building a new East Asian collection where there was none presented a daunting challenge, even when there was adequate financial support, as was the case in the 1960s. The problem was that there simply were not that many sources of supply of older publications needed by the new collections, particularly in Chinese, which was what most of the newly established collections were concentrating on. Nor was the procurement of current Chinese publications an easy task. The volume of publications from the People's Republic of China at that time was limited, and the Chinese government did not allow direct purchases by foreign libraries. Every book had to be acquired in Hong Kong or Japan. The number of new publications in Taiwan was also small, and the publishers did not aggressively engage in export. A number of them were busily engaged in reprinting block-print editions of centuries ago, exactly what was needed

9 Edwin G. Beal, Jr., "The Committee on East Asian Libraries: A Brief History," Committee on East Asian Libraries Newsletter, no. 41 (Sept. 1973), p. 48. For the full text of the Procedures, see Committee on East Asian Libraries Newsletter, no 40 (June 1973), pp. 35-37, reprinted in no. 49 (Mar. 1976), pp. 53-54.

${ }^{10}$ A report on the discussion of the revised Procedures before its adoption at the CEAL Plenary Session, held in Washington, D.C. is available in the Committee on East Asian Libraries Bulletin, no. 82 (June 1980), p. 3. The full text of the Procedures, as amended in 1984, is reproduced in Committee on East Asian Libraries Bulletin, no. 74 (June 1984), pp. 81-83.

When the Committee on East Asian Libraries was renamed the Council on East Asian Libraries in 1995, the designation "subcommittee" was replaced by that of "committee." At present there are nine standing committees: Committee on Chinese Materials, Committee on Japanese Materials, Committee on Korean Materials, Committee on Library Technology, Committee on Technical Processing, Committee on Public Services, Committee on Publications, Committee on Membership, and committee on Statistics. 
by the newly established East Asian libraries in the United States; but these reprints were mostly to satisfy Taiwan's own needs, and the publishers seemed oblivious of the overseas market. So, in 1963 CALRFE submitted a proposal to AAS for the establishment, under AAS auspices, of a Chinese Materials and Research Aids Service Center in Taipei for the benefit of American libraries. The purpose was to coordinate and reprint out-of-print titles needed by the Chinese studies community in the United States. With AAS approval and with initial grants from it, as well as from the American Council of Learned Societies (ACLS) and the Council on Library Resources (CLR), the Taipei Center was set up and began operation in the fall of 1964. Robert L. Irick, a Harvard Ph.D. in Chinese history, was appointed as director. Since then the Taipei Center, which later became independent under the name, has reprinted thousands of out-of-print titles and helped fill the shelves not only of American libraries, but also of foreign libraries that collect Chineselanguage publications. ${ }^{11}$

Meanwhile, current Chinese publications also demanded attention, particularly those from the People's Republic. As just mentioned, American libraries were not allowed to buy directly from China in the 1960s, and exchange was possible only with the National Beijing Library. Buying indirectly from Hong Kong or Japan was at best a poor substitute, as the supply was limited and many titles were not available at all because the Chinese government did not allow their export. At the time AAS was setting up the Taipei Center, an effort was also made to open up additional sources of supply of contemporary Chinese publications, especially those from the mainland. The Joint Committee on Contemporary China (JCCC), of the American Council of Learned Societies (ACLS) and the Social Science Research Council (SSRC), took the lead in this in hopes that the fast-growing teaching and research programs on contemporary China in the universities could be better supported. Toward that goal JCCC thought it important to find out how institutions in other countries were dealing with the problem of sources, especially contemporary publications, and see what we could learn from them. In 1964 I was commissioned by JCCC to conduct a survey and submit a report with recommendations. The survey was a year in the making, including visits to the major research and library centers in Chinese studies in Western and Eastern Europe, Scandinavia, the Soviet Union, India, Japan, Taiwan, Hong Kong as well as those in the United States. I found that a number of libraries in the Soviet Union and Eastern Europe, and to a lesser degree in Western Europe and Japan, were receiving research materials originating in the PRC in ways that were not available to us, and most of these libraries were receptive to the idea of exchange with American libraries. And so in the report submitted to JCCC, I recommended that a national service center for East Asian libraries be established to identify, procure (through interlibrary loans and exchanges), and reproduce for distribution contemporary Chinese publications unavailable to us and other hard-to-find research materials on 20th-century China available only in a very few American libraries. JCCC adopted this recommendation, and a not-for-profit organization, the Center for Chinese Research Materials (CCRM), was launched in 1968

${ }^{11}$ Committee on American Library Resources on the Far East Newsletter, no. 6 (Sept. 1964), p. 4. 
under the auspices of the Association of Research Libraries (ARL) in Washington, D.C., with a generous Ford Foundation grant. P. K. Yu, a Lecturer in History at the University of Hong Kong and owner of the prestigious Long Men Book Company in Hong Kong, was recruited as director. Additional grants from the Andrew Mellon Foundation, and the National Endowment for the Humanities made it possible for CCRM to become an academic publisher in a very short period of time. For more than three decades CCRM, now independently incorporated but still a not-for-profit organization under the directorship of Pingfeng Chi, has made available to libraries world-wide a great many once hard-to-find research materials on 20th-century China. It has become one of the most important support facilities for modern and contemporary China studies in the world, and Chinese collections in libraries everywhere would be much poorer today if not for CCRM.

In collecting PRC publications East Asian libraries have also benefited from significant and timely help from the American government. In the early 1960s when no Chinese local newspapers were available for subscription or purchase by foreign libraries, the government released to the Library of Congress its holdings of some 1,200 such papers published between 1949 and 1957. ${ }^{12}$ While the great majority of them were incomplete files, and many were very fragmentary (some containing only a few issues), the significance of this release cannot be overemphasized, as none of the publications was available elsewhere at that time. (Now we can read many of the local newspapers online free of charge!) The release of the Red Guard tabloids in 1967 by the State Department to the academic community was another case in point. Soon after the start of the Cultural Revolution in 1966, normal publishing in China was supplanted by the issuing of millions of copies of the Quotations of Chairman Mao and The Selected Works of Mao Zedong, and vendors in Hong Kong and Tokyo had little else to offer. So when reprints of a number of Red Guard tabloids began to appear in Hong Kong, they became instant best sellers. Although most of these publications were highly polemical, they contain a great deal of information and documentation taken from government archives which were not available elsewhere. The rarity and importance of these new sources made them must-have items overnight, and libraries from around the world competed with one another to acquire them, pushing the already high price charged for them even higher. The Joint Committee on Contemporary China (JCCC) (Chairman: John H. Lindbeck) was again asked for help. JCCC approached the State Department with the request that it consider sharing its collection of Red Guard materials with the academic community. The State Department responded in the affirmative, and invited JCCC to send a representative to Washington, D.C. to evaluate what they had and determine whether their release would indeed be helpful to the academic community as believed. JCCC asked that I undertake that mission. After examining samples of the materials made available to me by the State Department, I had no doubt about their research value and urged their immediate release. The materials

\footnotetext{
12 The content of this release is published as A List of China Mainland Provincial and Local Newspapers Held by the Library of Congress, 1949-1957 by the Orientalia Division of the Library of Congress, 1964. eld by Hed.
} 
thus released formed the bulk of the 20-volume Red Guard Publications issued by CCRM in 1975. This kind of government-academe cooperation is to be encouraged. It may be mentioned in this connection that CCRM has since collected from other sources many more Red Guard publications and has reprinted them in a total of 132 folio volumes for research purposes. This collection - published in 1975 (20 volumes), 1998 (20 volumes), 2001 (40 volumes), and 2005 (52 volumes) - is probably the largest publicly available Red Guard publications in the world.

I have dwelled on issues in Chinese collection development because they were the most pressing to the East Asian libraries in the 1960s and the 1970s. This is not to say that there were no problems in Japanese or Korean collection development work. Indeed, there were. Generally speaking, the Japanese case was not been a matter of availability but of cost. South Korea was like Japan in that respect; and there was a great resemblance between North Korea and China, at least in the early years, in terms of the difficulties involved in acquiring publications from them. The establishment of the National Coordinating Committee on Japanese Library Resources (NCC), funded by the Japan-U.S. Friendship Commission and the Japan Foundation, and of the Korean Collections Consortium of North America, funded by the Korea Foundation were two important milestones in the development of Japanese and Korean collections in American libraries.

\section{Technology in East Asian Libraries}

While general American research libraries were seriously exploring in the $1960 \mathrm{~s}$ and the 1970s the use of technology to improve operations, East Asian libraries were still occupied with the more mundane problems of cataloging standards and how to build or strengthen collections. Automation was far from everyone's mind and not on East Asian libraries' agenda. A 1975 statement CEAL was invited to submit to the Ford Foundation on the "Priorities for the Development and Funding of Library Programs in Support of East Asian Studies" made no reference to the role that emerging technology could play in East Asian library development. This was not East Asian libraries' fault. No serious work was being done on East Asian character codes in the United States at that time, and computers could not handle any of the East Asian languages. But the various needs outlined in the $1975 \mathrm{CEAL}$ statement to the Ford Foundation were both urgent and persuasive, and in the same year the Ford Foundation urged the American Council of Learned Societies (ACLS) to appoint a Steering Committee for a Study of the Problems of East Asian Libraries. The Steering Committee was composed of the following persons:

George Bechman, Professor of Asian Studies and Dean, College of Arts and Sciences, University of Washington (Chairman)

Albert Feuerwerker, Professor of History and Director, Center for Chinese Studies, University of Michigan 
Herman H. Fussler, Martin A. Ryerson Distinguished Service Professor, Graduate Library School, University of Chicago

Hanna H. Gray, Provost, Yale University

Warren J. Haas, Vice President for Information Services and University Librarian, Columbia University

William F. Miller, Provost and Vice President, Stanford University

Warren Tsuneishi, Chief, Orientalia Division, Library of Congress

Eugene Wu, Librarian, Harvard-Yenching Library, Harvard University

As a guide to its work, the Steering Committee commissioned a series of papers, a number of them written by CEAL members, including Karl Lo (University of Washington), T. H. Tsien (University of Chicago), Weiying Wan (University of Michigan), Raymond Tang (University of California-Berkeley), Thomas Kuo (University of Pittsburg), Thomas Lee (University of Wisconsin), Richard Howard (Library of Congress), Warren Tsuneishi (Library of Congress), and Eugene Wu (Harvard University). The Steering Committee made its report in 1977 under the title: "East Asian Libraries: Problems and Prospects" with recommendations for bibliographical control, collection development and access, and technical and personnel matters. ${ }^{13}$ The report attracted significant national attention, and in the following year ACLS, joined by the Social Science Research Council (SSRC), cosponsored a Joint Advisory Committee to the East Asian Library Program in order to continue the work begun by the Steering Committee. The following persons were appointed to the Joint Advisory Committee:

Patricia Battin, Vice President and University Librarian, Columbia University Charles Churchill, Dean of Library Services, Washington University (for 1980-1981) Hideo Kaneko, Curator, East Asian Collection, Yale University Library

W. Mote, Professor of East Asian Studies, Princeton University

Robert E. Ward, Director, Center for International Studies, Stanford University

Eugene Wu, Librarian, Harvard-Yenching Library, Harvard University

John W. Haeger (ex-officio), Director, ACLS-SSRC-ARL East Asian Library Program

It was the work of this committee that eventually led to online cataloging in East Asian libraries. In its report on "Automation, Cooperation, and Scholarship: East Asian Libraries in the 1980s,"14 the Joint Advisory Committee stated that "after a decade of unprecedented growth along a course linked primarily to foreign area studies programs rather than to the development of research libraries in general.... East Asian libraries were at a crossroad," and with the lessening of federal and foun-

${ }^{13}$ East Asian Libraries: Problems and Prospects, A Report and Recommendations, prepared by the Steering Committee for a Study of the Problems of East Asian Libraries (Washington, D.C.: The American Council of Learned Societies, 1977).

${ }^{14}$ Automation, Cooperation and Scholarship: East Asian Libraries in the 1980's, Final Report of the Joint Advisory Committee to the East Asian Library Program (Washington, D.C.: The American Council of Learned Societies, 1981). 
dation funding, they ought to embark upon a new course of sharing work, materials, and access, and of relying "on automation as a principal planning and management tool." The keystone to this, according to the report, "is the capability to input, manage, store, transmit, display and output bibliographic records containing East Asian vernacular characters in exactly the same automated systems already created to perform similar functions for Western language materials and general research libraries." This basic reorientation of the course of development of East Asian libraries in North America, as advocated in the report, would fundamentally change the way East Asian libraries operated, but it was welcomed by all concerned.

The immediate result of the Joint Advisory Committee's recommendation was the decision by the Research Libraries Group (RLG) to introduce in 1983, with Ford Foundation support, the CJK enhancements to the Research Libraries Information Network (RLIN), RLG's operating arm. This move made possible for the first time the creation of cataloging records at one library which could then be copied by other libraries and also viewed by researchers everywhere. In 1986 the Online Computer Library Center (OCLC) also established a similar CJK bibliographic utility. The rest, of course, is history.

\section{Remembering the Pioneers}

As we reminisce about our past, it is important that we honor the pioneers in our profession. I would like to salute two of them in particular, as I knew them the best: A. Kaiming Chiu (1898-1977) and Mary Clabaugh Wright (1917-1970). Dr. Chiu was the first Librarian of Harvard-Yenching Library and served in that position with great distinction for thirty-eight years, from 1927 to 1965. Dr. Wright was the first Curator of the Chinese Collection at the Hoover Institution, Stanford University, for eleven years, from 1948 to 1959 . I had the singular honor of succeeding both of them, Mary Wright in 1959 when she was appointed a professor of history at Yale University, and Kaiming Chiu in 1965 when he retired from Harvard-Yenching Library.

Dr. Chiu's name has long been synonymous with East Asian librarianship in the United States. He was the very first person to be appointed Librarian of an East Asian library at an American university, and his tenure of almost four decades at the Harvard-Yenching Library remains to this day the longest among the nation's East Asian librarians. But his legacy lies elsewhere. He will be remembered for his Harvard-Yenching Classification Scheme, the first such work for cataloging Chinese, Japanese, and Korean books in the Western world. The scheme was adopted for use by the major East Asian libraries in the United States and several leading East Asian collections in Europe and Australia until the 1970s and the 1980s. He will also be remembered for putting romanization along with the vernacular script on the catalog card, something we take for granted today, and for introducing separate catalogs and shelving by language. Dr. Chiu was also a great mentor. A number of people he trained at the Harvard-Yenching Library later achieved prominence, among them were James S. K. Tung, who became Assistant University Librarian 
and Curator of the Gest Library and Oriental Collections at Princeton; Fang Chaoying and Tu Lien-che, known for their impeccable scholarship on Ming and Ch'ing history, who collaborated with Dr. Arthur H. Hummel and Professor L. Carrington Goodrich respectively in the compilation of Eminent Chinese of the Ch'ing Period and Dictionary of Ming Biography, two publications of lasting importance to Chinese studies; Tien Hung-tu, who became Librarian of Yenching University Library; Teng Yen-lin, who served as the Reference Librarian at the National Library of Peking, and Chen Hung-shun) who taught at the Department of Library Science at Peking University after 1949. Of course, his greatest legacy is the collection he built at the Harvard-Yenching Library. He was a giant in this respect, as he succeeded in building from almost nothing one of the greatest libraries for East Asian research in the Western world. It is unlikely that his accomplishments will ever be duplicated. In the words of the Trustees of the Harvard-Yenching Institute who paid him tribute upon his retirement, he was "a scholar who exemplifies the best in the traditions and accomplishments of both East and West."15

Prof. Mary C. Wright was another legendary library builder. Trained as a historian at Harvard, she was with her husband, Arthur Wright, in Peking when Pearl Harbor came. Subsequently they were interned by the Japanese in Wei Xian in Shandong for the duration of the War. When the War ended, she accepted an offer from the Hoover Institution at Stanford University to collect materials for a Chinese Collection that was being planned at Hoover. Since Hoover's main interest was, and still is, in modern and contemporary affairs under the rubric of "War, Peace, and Revolution," Mary Wright was asked to focus on her acquisitions work accordingly. This she did, with entrepreneurial energy, skill, resourcefulness, and imagination. She traveled to all the major cities in China, sought advice from eminent scholars and bibliographers, badgered government agencies for their publications, and negotiated exchange agreements with major libraries and universities. Her painstaking efforts resulted in tons of materials, including a large number of journals, newspapers, and other ephemeral materials that are essential to social science research and which up to that time had not been systematically collected by most other libraries. Mary Wright did not confine herself to the ordinary channels in her collecting activities. In 1947, having wangled a seat on a U.S. military transport, she flew to Yenan, the base of the Chinese Communist Party, where she succeeded in obtaining a large group of Chinese communist publications issued there and in other communist-controlled "border areas". Such publications were not even available elsewhere in China at that time. The almost complete set of the Jiefang Ribao (Liberation Daily), the official organ of the Chinese Communist Party, she acquired on this excursion remains to this day the only original copy in the Western world. Following her return to the United States in late 1947, she managed to acquire the Harold Issacs Collection, a group of underground Chinese communist publications of the late 1920s and early 1930s collected by Mr. Issacs in Shanghai in the 1930s when he was editor of the China Forum. Soon after wards she reached

${ }^{15}$ For a chronological biography of Dr. Chiu, see 程焕文编, 《表开明年谱》, 哈佛燕京图书馆 学术丛刊第九种。桂林:广西大学出版社, 2008. 
agreement with Nym Wales (Helen Snow) for the sale to Hoover of the Nym Wales Collection, containing Chinese communist and other related publications and documents of the mid- and late 1930s collected by Edgar Snow and Nym Wales when they visited Northwest China. The Harold Issacs and Nym Wales Collections together provided the basis for much of the subsequent research on the early history of the Chinese Communist movement by scholars from all around the world-a task theretofore impossible for lack of documentation. ${ }^{16}$ As a scholar and librarybuilder, Mary Wright left us with a lifetime of work rich in insight and inspiration. As a pioneer in East Asian librarianship, she provided vision and ingenuity in her collection-building efforts. She supplied the necessary perspective as a scholar and active library user on what a research library should be and how it should function, and then went about creating such a library. ${ }^{17}$ (It may be mentioned in this connection that Hoover's collection of the primary documentation for the early history of the Chinese Communist Party was made complete by the acquisition of the Jiangxi Soviet Government documents, commonly known as the Chen Cheng Collection which I microfilmed in Taipei in 1960. $)^{18}$

\section{The Future}

It is often said that only fools make predictions. And so I will make none here as to where East Asian libraries will be in another ten, twenty or fifty years. But I do want to say a few words about technology and East Asian libraries as we enter a new millennium. High technology has done wonders. It has made it possible for libraries to do things that were hardly imaginable ten or twenty years ago. Libraries can now manage much more efficiently and serve their users much more effectively. Information is now available at our fingertips. We can search the catalog in a university library or view a museum collection in China, Japan, Korea or anyplace else. We have access to digitized databases, and their number is growing rapidly. We can read journals and newspapers online and order copies. We have tens of thousands, perhaps hundreds of thousands of specialized web sites that provide information

${ }_{16}$ The most important items in the Harold Issacs Collection and the Nym Wales Collection are annotation by Prof. Chun-tu Hsueh and published under the titles The Chinese Communist Movement, 1921-1937 and The Chinese Communist Movement, 1937-1949. The Hoover Institution Bibliographical Series VIII and XI (Stanford: The Hoover Institution on War, Revolution, and Peace, 1960 and 1962).

${ }^{17}$ See also Eugene Wu, "Mary Clabaugh Wright: A Memorial," China Quarterly, no. 43 (July-September 1970), pp. 134-135.

18 The Jiangxi Soviet documents, totaling approximately 1,500 items, are on 21 reels of microfilm. A selection of 670 of them was annotated by Prof. Tien-Wei Wu and published under the title, The Kiangsi Soviet Republic, 1931-1934, A Selected and Annotated Bibliography of the Chen Cheng Collection. Harvard-Yenching Library Bibliographical Series III. (Cambridge, Mass.: Harvard-Yenching Library, Harvard University, 1981) The content of the entire microfilm collection is listed at the end of the publication by the microfilm reel number and then by the title of the document. 
of every kind. And the list goes on. High technology will undoubtedly continue to develop, and libraries and library users will all benefit. Although the unprecedented contribution high technology has made to libraries and scholarship has been huge and most likely will be even greater in the future, we must be mindful that technology is but the means to achieve an end, and not the end itself. While we continue to employ new technology in the service of scholarship, we must also continue our efforts to build collections as we have in the past. For in the final analysis, what scholarship demands of libraries is the substance of information, and that substance can only come from what libraries are able to collect. In the words of the great American naturalist, Henry David Thoureau, who made Walden Pond famous, we cannot afford to have "improved means to an unimproved end." It will serve us well as librarians to remember these words as we proceed with digital libraries and apply more technology to our work.

Open Access This chapter is distributed under the terms of the Creative Commons Attribution Noncommercial License, which permits any noncommercial use, distribution, and reproduction in any medium, provided the original author(s) and source are credited. 